The method for determining the minimum sample volume necessary for controlling porosity has been successfully implemented in the production of air tanks R7-78 in combination with statistical control of the production process.

A method for reducing technological risks, based on determining the minimum required sample size, seems to be quite universal and can be recommended for controlling defects with known (predicted) occurrence probabilities.

\title{
References:
}

1. Fomichov, S., Banin, A., Skachkov, I., Lysak, V., Gaievskiy, O., \& Yudina, N. (2019). Standard Management Systems. Quality Management. Kyiv: KIM.

2. Prokhorenko, V. M., \& Haievskyi, V. O. (2014). Jmovirnistj nevykonannja vymogh do porystosti shva pry zvarjuvanni pid flju-som [The probability of failure to meet the requirements for the porosity of the seam when welding under flux]. Technological systems, vol. 3, no. 68, pp. 33-41. (in Ukrainian

3. Rybakov, I. N. (2009) Analiz vidov i posledstviy potentsialnykh otkazov. FMEA. Ssylochnoe rukovodstvo [Analysis of the types and consequences of potential failures. FMEA. Reference guide]. Nizhniy Novgorod: «Prioritet» Publ. (in Russian)

4. Gaievskiy, V., Prokhorenko, V., \& Ziberov, M. (2014). Limitation of risks of non-compliance of weld metal porosity. Graduação em Engenharia Mecânica, vol. 1. pp. 4-7.

\section{PROBLEMATIC ASPECTS AND WAYS TO INCREASE THE LEVEL OF METALLURGICAL SLAGS DISPOSAL}

\section{Mykhailo Petlovanyi ${ }^{1}$ Oleksandr Filonenko ${ }^{2}$}

DOI: https://doi.org/10.30525/978-9934-588-13-6-17

Functioning of the industrial complex of Ukraine is characterized by a high level of waste formation, resulting in more than 30 billion tons of solid waste, accumulated on the daylight surface of Ukraine [1, p. 24; 2, p. 46]. The metallurgical industry is one of the leading sectors of the Ukrainian economy, hence, it plays an important role in the functioning of the economy, providing inflow of foreign currency to the nation's budget at the level of $40 \%$. Instead,

\footnotetext{
${ }^{1}$ Dnipro University of Technology, Ukraine

2 Dnipro University of Technology, Ukraine
} 
in the process of the main products development (pig-iron smelting, steel melting), large-tonnage waste in the form of metallurgical slags is formed, which is not sufficiently used as raw material, and what is more, valuable land areas are allocated for its accumulation [3, p. 115]. Technogenic accumulation, including metallurgical slags, has a negative impact on the environment [4, p. 1; 5, p. 77].

More than 250 million tons of metallurgical slags have been accumulated within the territory of Ukraine, of which 130 million tons are steelmaking slags $[6$, p. $40 ; 7$, p. 220]. The metallurgical production wastes, as well as tailings, occupy large areas for emplacement. Serednia Balka, located near to Zaporizhia city, is the largest dump of metallurgical slags in Ukraine, where the waste from three industrial enterprises - Zaporizhstal, Dniprospetsstal, Zaporozhsky Ferroalloy Plant - is emplaced (Figure 1).

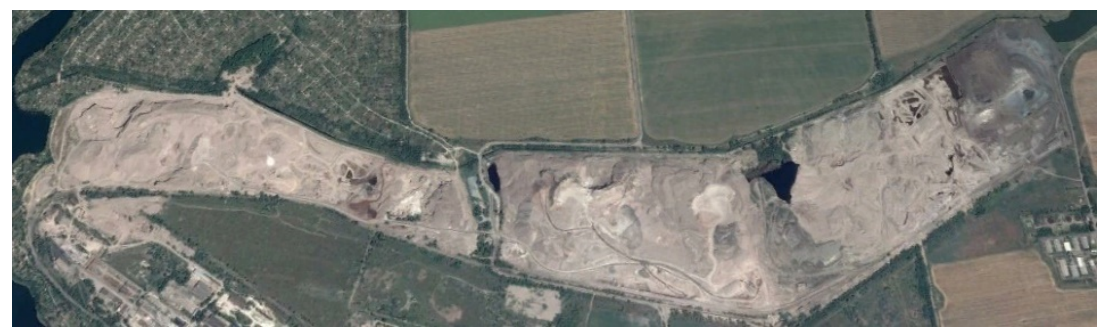

Figure 1. The largest in Ukraine area of metallurgical slags dumping (240 ha), Serednia Balka (Zaporizhia city)

As a rule, the metallurgical slag dumps are located outside settlements, thus, the negative impact from them, first of all, is experienced by such environmental components as soils, surface watercourse and atmospheric air [8, p. 22]. Therefore, the problem of recycling the accumulated metallurgical slags in Ukraine is constantly relevant for the Ukrainian society and has an environmental and economic justification for accelerating its solution vacating the valuable land from technogenic accumulation with its subsequent return to agricultural or other type of use.

At present, the following directions for recycling the metallurgical slags are known:

- construction sector (slag cements, dry building mixes, slag concrete);

- roads and railroads construction (crushed stone for the lower layers of pavement, mineral powder);

- agricultural sector (mineral fertilizers for acidic soils); 
- processing and a partial return to the manufacturing cycle (extracting scrap from slag, partial limestone replacement);

- backfilling material for recultivation of the mined-out space of mine workings (cementing or inert component).

The implementation of these directions of metallurgical slags disposal in various sectors of the Ukrainian economy is characterized by a rather low level of their recycling - at the level of $45 \%$, while in the EU countries the indicator reaches $90 \%$ [9, p. 1]. Every year, the accumulation of metallurgical slags, in spite of a partial disposal, continues to increase, which undoubtedly makes an impact on the environment. The transport and logistics component significantly affects the level of slag disposal. The cost for transporting this recoverable resources for further usage by consumers, as a rule, is several times higher than the sale price of the unit itself of the slag product. Therefore, in some cases it will be rational to manufacture the products from slag of a higher technological process stage (for example, mineral additives or paving slabs) near metallurgical enterprises and sell them at an extra cost than transporting raw materials to the consumer.

To increase the volume of recycling the slag, it is necessary to revise the existing regulatory acts and regulatory-technical documents. An especially important step at the legislative level will be the creation of a 'green list' for public procurements, which should include potentially valuable secondary products of industrial manufacturing. At the government level, sectoral and intersectoral recycling programs should be developed and comprehensively supported [9, p. 1]. In general, in the context of the current level of economic development of the country, it is impossible to solve the issue of fast and fullscale metallurgical slag disposal. But to gradually reduce the problem acuteness, a more flexible strategic approach is required, which will result also in solving all the other attendant problems of the industry.

As a result of mineral resources extraction, the technogenic voids are formed in the earth's crust. In case of underground mining activity, the minedout space of mine workings may eventually lead to deformations of the daylight surface. To prevent the soil subsidence, the backfilling is performed of the mined-out space with solidifying mixtures [10, p. 465; 11, p. 383]. In these mixtures, significant volumes of metallurgical slags can be disposed of as cementing or inert aggregate materials. As a result of the mixture hardening, a technogenic, monolithic, artificially created massif is formed in the bowels, which ensures the rock massif stability [11, p. 183; 12, p. 75]. During the open-pit (quarry) mining, the technogenic voids are open and have an access to the daylight surface [14, p. 1]. After mining the industrial mineral reserves of the quarry, the mined-out space remains, the remaining reserves are written off from the balance sheet and the recultivation measures of 
disturbed lands should be implemented. The mined-out space of the quarry, depending on the situation, can be measured in millions of cubic meters.

In compliance with the current legislation of Ukraine, the recultivation measures are mandatory in case of disruption of the landscape integrity in the process of the enterprise economic activity. The type of recultivation in each case is substantiated, based on an assessment of a complex of factors (estimated monetary value of land and its purpose in the national economy, agrochemical composition of overburden rocks, geographical location, socioeconomic factors, etc.) [15, p. 206]. According to the project, the rock refuse (overburden and non-standard) can be placed in the mined-out space of the quarry at the mining-engineering stage of recultivation.

A promising direction for recycling the metallurgical slags can be their emplacement in the mined-out space of quarries, close to metallurgical enterprises, since they have a hazard class IV. When performing the miningengineering stage of recultivation, it is necessary to scientifically substantiate the use of slags instead of waste rock. The positive aspects of this direction implementation will be primarily a high level of the metallurgical slags disposal. The waste rock dumps can be used at the stage of biological recultivation after appropriate measures of the mining-engineering stage. Even if the waste dumps of the very quarries are not fully utilized, they are safer for the environment due to their natural origin.

Thus, before to implement this direction of recycling, it is necessary to solve a number of priority scientific problems:

- examine the state of the quarry provided that it is ready for recultivation;

- investigate the impact of metallurgical slags on soils and substantiate the necessity for emplacement and parameters of a reliable safety shield between the quarry bottom and the metallurgical slags bulk;

- substantiate the sequence and scheme of layers allocation of metallurgical slags with a certain granulometric composition in the mined-out space of the quarry;

- study the balance and optimal existence of the 'layer of metallurgical slags - fertile soil layer' system, as well as to substantiate the specific vegetation types for mechanical soils fixation.

\section{References:}

1. Petlovanyi M., Kuzmenko O., Lozynskyi V., Popovych V., Sai K., Saik P. (2019). Review of man-made mineral formations accumulation and prospects of their developing in mining industrial regions in Ukraine. Mining of Mineral Deposits, vol. 13, no. 1, pp. 24-38. https://doi:10.33271/mining13.01.024

2. Hrinov V. H., Khorolskyi A. O., Kaliushchenko, O. P. (2019). Rozroblennia ekolohichnykh stsenariiv efektyvnoho osvoiennia tsinnykh rodovyshch korysnykh kopalyn [Elaboration of environmental scenarios for the effective development of 
valuable mineral deposits]. Mineral Resources of Ukraine, no. 2, pp. 46-50. https://doi.org/10.31996/mru.2019.2.46-50

3. Filonenko O. (2018). Sustainable development of Ukrainian iron and steel industry enterprises in regards to the bulk manufacturing waste recycling efficiency improvement. Mining of Mineral Deposits, vol. 12, no. 1, pp. 115-122. https://doi:10.15407/mining12.01.115

4. Popovych V., Kuzmenko O., Voloshchyshyn A., Petlovanyi M. (2018). Influence of man-made edaphotopes of the spoil heap on biota. E3S Web of Conferences, vol. 60, pp. 00010. https://doi:10.1051/e3sconf/20186000010

5. Khomenko O. E., Kononenko M. N., Mironova I. G., Yurchenko K. O. (2017). Puti snizheniya tekhnogennoy nagruzki na gornodobyvayushchie regiony Ukrainy [Ways of technogenic loading decreasing on mining regions of Ukraine]. Collection of Research Papers of the National Mining University, no. 51, pp. 77-83.

6. Kanenko G. M., Zlobin A. G. Zdorov A. I., Zlatkovskiy A. B. (2005). Ispol'zovanie otkhodov metallurgicheskikh predpriyatiy $\mathrm{v}$ stroitel'noy industrii [Utilization of waste from metallurgical enterprises in the construction industry]. Ecology and Industry, no. 1, pp. 40-43.

7. Aleshin A. A., Kazachkov E. A., Ostroushko A. V., Pustovalov Yu. P., Chichkarev K. E (2007). Povyshenie effektivnosti pererabotki tverdykh metallurgicheskikh shlakov [Improving the efficiency of processing solid metallurgical slag.]. Bulletin of the Azov State Technical University, no. 17, pp. 220-223.

8. Pavlychenko A., Buchavyy Y., Fedotov V., Rudchenko A. (2017). Development of methodological approaches to environmental evaluation of the influence of manmade massifs on the environmental objects. Technology Audit and Production Reserves, vol. 4, no. 3(36), pp. 22-26. https://doi:10.15587/2312-8372.2017.109243

9. UNIAN (2019). V Ukraini utylizuietsia vdvichi menshe metalurhiinykh shlakiv, nizh v YeS [In Ukraine, twice as much metallurgical slag is disposed of as in the EU]. Kyiv, Ukraine: UNIAN.

10. Kuzmenko O., Petlyovanyy M., Heylo A. (2014). Application of fine-grained binding materials in technology of hardening backfill construction. Progressive Technologies of Coal, Coalbed Methane, and Ores Mining, no. 1, pp. 465-469. https://doi.org/10.1201/b17547-79

11. Kuz'menko A. M., Petlevanyy M. V., Usatyy V. Yu. (2010). Vliyanie tonkoizmel'chennykh fraktsiy shlaka na prochnostnye svoystva tverdeyushchey zakladki [Influence of finely ground slag fractions on the strength properties of the hardening backfill]. Proceedings of the School of Underground Mining (Ukraine, Haspra, October 3-7, 2010) (eds. Pivniak H. H., Bondarenko V. I., Kovalevska I. A.), Dnipro: National Mining University, pp. 383-386.

12. Petlevanyy M. V., Kuz'menko A. M., Gorobets L. Zh., Pryadko N. S., Usatyy V. Yu. (2011). O mekhanicheskoy aktivatsii komponentov tverdeyushchey zakladki dlya zapolneniya vyrabotannogo prostranstva rudnikov [On the mechanical activation of hardening backfill components to fill the mined-out space of mines]. Metallurgical and Mining Industry, no. 3, pp. 75-78.

13. Kuzmenko O., Petlovanyi M. (2015). Substantiation the expediency of fine gridding of cementing material during backfill works. Mining of Mineral Deposits, vol. 9, no. 2, pp. 183-190. https://doi.org/10.15407/mining09.02.183 
14. Anisimov O., Symonenko V., Cherniaiev O., Shustov O. (2018). Formation of safety conditions for development of deposits by open mining. E3S Web of Conferences, vol. 60, pp. 00016. https://doi:10.1051/e3sconf/20186000016

15. Fedoniuk V. V., Volianskyi V. O., Fedoniuk M. A. (2016). Porivnialnyi ekonomichnyi analiz provedennia rekultyvatsii riznykh vydiv na porushenykh zemliakh [Comparative economic analysis of the reclamation of different species on disturbed lands]. Actual Problems of the Economy, no. 9, pp. 203-212.

\section{THE RESEARCH OF TECHNOLOGICAL PROCESS OF GRAIN EXTRUSION WITH VEGETABLE COMPONENTS}

\section{Ivan Ulianich ${ }^{1}$ \\ Igor Didenko $^{2}$}

DOI: https://doi.org/10.30525/978-9934-588-13-6-18

According to scientists, most vegetable plants for their economic purpose provide valuable products that should be used as a food and feed. Many vegetable plants have a large amount of nutrients and vitamins, preserving, antiseptic and bactericidal properties, which is extremely important for improving the quality of feed [1-7].

The purpose of the experiment. To develop optimal indicators of technological process of grain extrusion with vegetable components on the basis of multivariate experiment.

Research methodology. The experimental part was performed at the Department of Grain Storage and Processing Technology and at the Scientific Laboratory of Mass Analysis (attestation № AO6-203 of 25.10.16) of Uman NUS. The research were conducted in accordance with conventional methods. The technological process of grain extrusion with beet was adopted as the object of research. The data obtained was processed using Microsoft Excel applications and STATISTICA for Windows software.

The planning of the experiment was carried out by the method of steep ascent, or the Box-Wilson method, with the subsequent construction of a mathematical model of the process. Based on the chosen plan, we built a model that corresponds to the review under consideration, and used known methods of finding the extremum to find the values of the factors for which the selected objective function defined in the model will be extreme. If the

\footnotetext{
${ }^{1}$ Uman National University of Horticulture, Ukraine

${ }^{2}$ Uman National University of Horticulture, Ukraine
} 